\title{
GEOLOGY AND DEVELOPMENT OF AGUACATE MINES, COSTA RICA
}

\author{
R.A. Crespi \\ Transcrito por: \\ Siegfried Kussmaul
}

Escuela Centroamericana de Geología, Universidad de Costa Rica

\author{
Documento original tomado de: The Mining World, \\ November 9, 1907: págs. 847-848
}

The Aguacate mines are situated on the Pacific side of the republic of Costa Rica, in the Aguacate mining zone, province of Alajuela, and consist of about 1,500 acres. The Property is reached by steamers sailing from Atlantic ports of the United States to Port Limon, the Costa Rican port of entry on the Atlantic seaboard ; from here by rail (United Fruit Co.'s road), 102 miles to San Jose, the capital of the republic ; then by the government Pacific railway, a distance of about 30 miles to Hacienda Vieja, a station on that line ; then by cartroad a distance of about three miles to the mines.

The property can also be reached by Pacific Mail steamers to Puntarenas, the Pacific port of entry ; then to Esparta, a distance of about 13 miles by the government Pacific railway ; then by cartroad a distance of about 20 miles to the mines. The connecting link of about seven miles is now under construction, and will be completed within the next
18 months, thus giving a through railway from the Atlantic to the Pacific. Machinery can be delivered by United Fruit Company's steamers sailing from Mobile, New Orleans, New York, Boston, etc., to Port Limon, and over that company's railway to San Jose.

The elevation of the mines is about $2,800 \mathrm{ft}$. above sea level, and about 1,800 ft. above the railway.

\section{Geological and Mineral Features}

The country rock is of igneous origin. The vein matter consists of quartz and a mixture of clay, porphyry and quartz. The quartz is mostly decomposed, and in some veins is heavily stained by dioxide of manganese. This is characteristic of the Paciencia vein in particular. The general strike of all these veins is north and south, and 
the veins, being almost vertical, are easily worked, and their position can be determined with reasonable certainty in laying out the system of development proposed.

\section{History}

From the old official reports and other information gathered from people familiar with the history of these mines, I gather the following data relative to their early history: The mines were first discovered in 1815, and it was the gold extracted form the Monte Del Aguacate [Fig. 1] which infused the first symptoms of vitality into Costa Rican commerce.

The mines are the oldest worked in the district, and it is said that a great many men were employed at one time, working the ores in a series of arrastras, and many evidences of this work are still visible. A large part of the early work consisted of open cuts upon the veins, and, from appearances, the entire vein matter from these cuts was extracted and worked. Most of these cuts vary from 30 to $50 \mathrm{ft}$. in depth, and I estimate that there is an aggregate of about 5,000 $\mathrm{ft}$. in length of these old cuts upon the different veins. Most of these old cuts have partially caved and filled in with wash, and are now filled with trees and rank growths of vegetation. In addition to the open cuts, there were numerous underground workings, the lowest level of which was, so far as known, the San Juan tunnel, which underground workings aggregate fully 30,000 ft. of crosscuts, drifts and raises. In these different underground workings above the San Juan level no timbering was used, as the old mining laws provided that floors and pillars should be left in place. Therefore, on account of the old method of working, with rare exceptions, nearly all of these ancient works are intact and in good condition and not over $33 \%$ of the ores has been extracted.

The production of gold from the mines of this district is shown by Costa Rica government official mint returns to have been over $\$ 10,000,000$, but the total probably exceeded this figure.

The property along these veins was divided into many separate mining claims, owned by different individuals. No one individual owned enough claims nor possessed sufficient capital to undertake systematic development, particularly to open up the veins at depth. At that time there were no railroads in the republic ; it was practically impossible to bring in modern machinery for pumping and power purposes, even had the owners possessed the capital. Modern methods of mining and of treating ore were unknown; the cyanide process had not been developed. Manual labor for all mining purposes, including hoisting and carrying ores, had to be depended upon. The ore was treated in arrastras, probably saving not over 30 to $40 \%$ of the values, and were operated only during the rainy season, because there was not sufficient water in the nearby creeks to supply power during the dry season. Electric transmission was unknown, and it was not possible to bring power to the mines from the Rio Grande river, three miles away. It was a natural consequence, therefore, that without machinery for pumping or power purposes, the owners found it impracticable to work the mines below the drainage level established by the deepest tunnel in the veins, and that gradually all of the mines were compelled to stop work.

Don Demetrio Yglesias, formerly vice-president of Costa Rica, owing some of the mining claims, gradually acquired all of the other claims along these veins, and then undertook to drive the San Juan, a lower level tunnel, for more systematic development. The greater values have been obtained from the assays at great depths. There is every reason for believing, and none for doubting, that the veins and values continue to great depth, and that Don Demetrio Yglesias' belief in the future of the property and plan of systematic development were correct. He died, however, about three years ago, before the work was completed, and the property passed into the hands of his estate.

It is, of course, impossible to accurately estimate the amount of ore previously removed from these veins, but from present surveys, it would appear that over 100,000 tons were removed from the open cuts, and fully 200,000 tons from the underground workings, from the various veins. As to the value of the ores taken out of these old workings, it would be difficult to state. 


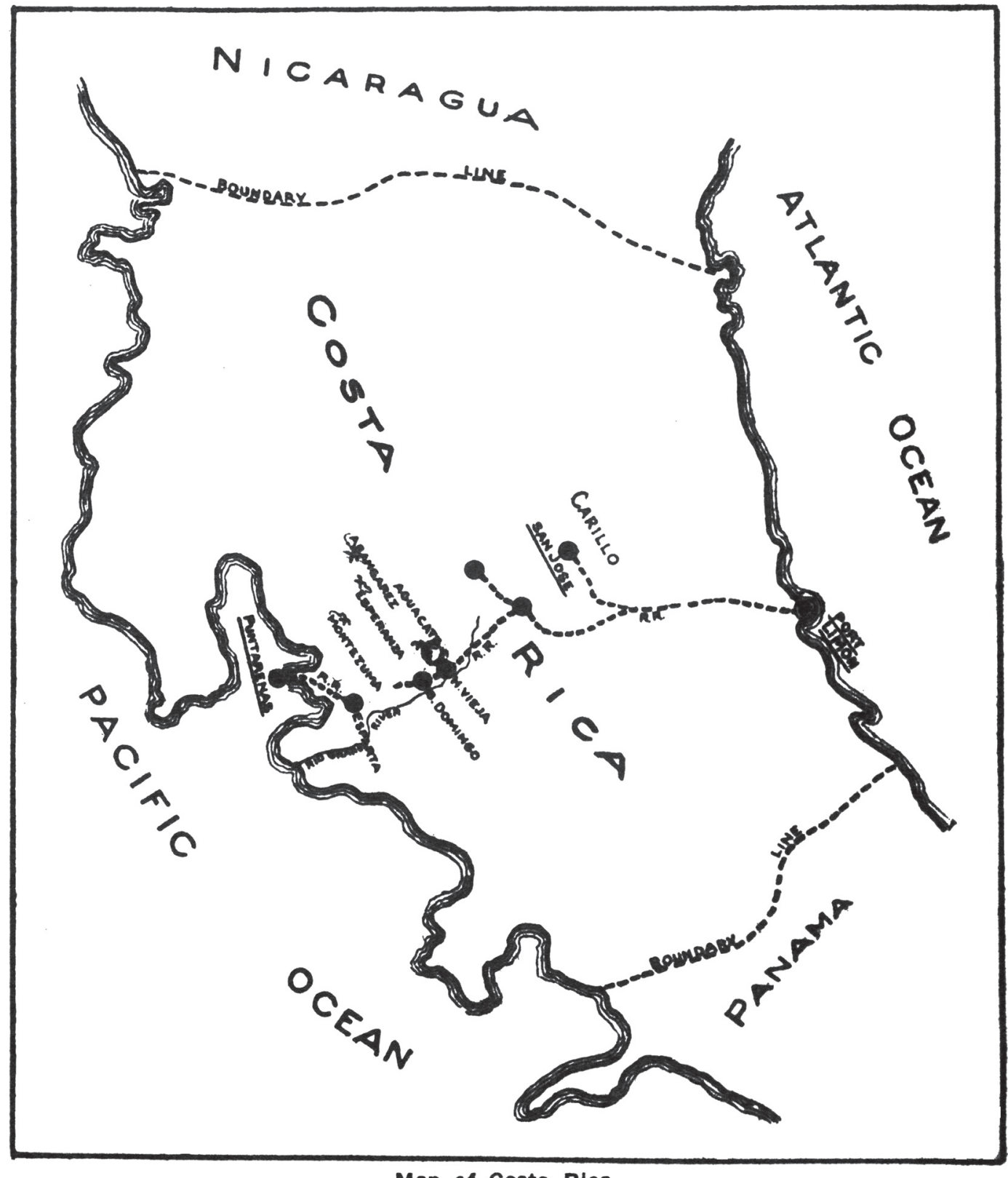

Fig. 1: Mapa de Costa Rica (tomado de: The Mining World, 1907)

Veins

The vein system consists of nine known veins upon all of which more o less work has been done and their character and size determined with reasonable certainty, and may be briefly described as follows: [Table 1]

Active work is being carried on now by the Aguacate Mines, Incorporated, of 43 Exchange place, New York city, in opening up the old works and 
Table 1

Vein system size

\begin{tabular}{lc}
\hline & Width, feet \\
\hline 1. Paciencia vein & 6 to 14 \\
2. Aguilar & 4 to 8 \\
3. Torres No.1 (rich) & 1 to 2 \\
4. Torres No. 2 (rich) & 1 to 2 \\
5. Ujurras & 4 to 6 \\
6. Esperanza (rich) & 3 to 5 \\
7. Pilar & 3 to 5 \\
8. Padre Arias No. 1 & 6 to 8 \\
9. Padre Arias No. 2 & 2 to 3 \\
\hline
\end{tabular}

developing the Paciencia and other veins, and I estimate that the quantity of ore available at the present time in the old workings of the Paciencia vein, above the level of San Juan tunnel, is fully 300,000 tons, and that in the other veins there are many 200,000 tons of ore, giving a total now blocked out of over 500,000 tons. Another tunnel, $200 \mathrm{ft}$. lower, is now under way, which should develop above its level at least $1,000,000$ tons of ore additional.

The Esperanza vein is now being developed below the old workings to open up the rich ore bodies previously worked. The records show that ore from this vein, when mined in large quantities, average $\$ 30$ to $\$ 60$ per ton, and from assays made it is confidently predicted that the ore from this vein will average fully $\$ 25$ per ton at the mill.

All the other veins show ore of good, profitable milling qualities. In all my sampling of the different veins upon this property, I found the values to be unusually uniform throughout the entire width of different points along the veins, and at no place was the ore without gold value, which indicates that the entire vein matter can be profitably mined. My own pannings and assays from various parts of the several veins show values running from $\$ 5$ to $\$ 100$ per ton.

The ores are free milling, and there is no evidence of a rebellious nature which might interfere with the extraction of the gold by amalgamation and the ordinary cyanide process.

\section{Climate, Water Power and Timber}

The climate is remarkably good and the district is considered the most healthful in the republic. Observations taken at the Aguacate mines indicate an average temperature of 72 degs. F. The temperature varies little during the entire year.

The supply of pure water is sufficient for all purposes. The Rio Granderiver, at the foot of the Aguacate mines and running parallel with the railway, could be developed to provide power for operating machinery. Ten thousand horsepower are obtainable on this river for the development of a hydro-electric plant.

The native woods are well adapted for mining purposes and sufficient to supply this demand for many years.

\section{Labor}

Native labor is good, cheap and steady. The Costa Rican miner is hard working and intelligent. The maximum price paid for hand drill men is 3 colones ( $\$ 1.35$ ) per day, and ordinary labor is secured for about half this price. The average of all wages would be about $\$ 1.25$ per day.

As a summary of these facts, it is conservative to say that all economic conditions are favourable to profitable operations.

Mining machinery and supplies are admitted free of duty and there is no taxation of any nature on mining property or its production. The attitude of the government is especially friendly towards the development of mining industries. 